\title{
Information Literacy Assessment: A Case Study at Miami University
}

\section{Structured Abstract}

Purpose - This case study, created by a Faculty Learning Community on Research Fluency, investigated students' information literacy practices at Miami University, including information search process, preparation, differences in students' information literacy skill levels, and how well they transfer these skills outside coursework.

Design - Faculty and librarians designed a survey of about 60 questions, which were given to 300 students in faculty's classes by librarian FLC members.

Findings - FLC members discovered where perceptions among professors, librarians, and students were similar, and where they differed.

Practical implications - Influenced by the findings, participating faculty made changes to the course plans and included additional assignments to make the process of research more explicit. Originality/value - While there are similar studies about information literacy, the Miami University study is distinct in that it reports on collaboration with faculty and makes use of their perceptions of students.

Keywords - faculty collaboration, survey, learning community, information literacy Paper type - Case Study

\section{Literature Review}

Literature discussing collaborations between librarians and faculty abound. Case studies detailing successful librarian and faculty partnerships to embed information literacy into course curriculum are the most common. Deitering and Jameson (2008) described a collaborative effort between an instruction librarian and a faculty member to incorporate information literacy skills 
into a required undergraduate composition course. The main assignment was broken into assignments for each step of the research process. Lampert (2005), noting a lack of scholarship relating to developing subject-specific information literacy skills in graduate students, described work done by librarians and the Educational Psychology and Counseling graduate program to incorporate information literacy competencies into the program's learning outcomes. Young and Duvernay (2006) expounded on a relationship between a librarian and living learning community instructors to incorporate information literacy into the interdisciplinary first year curriculum. Love and Norwood (2007) worked with faculty to provide reference assistance and information literacy instruction to students in an online history course. As the project developed, their role grew into team teaching with librarians evaluating information literacy components of students' projects. Another approach frequently taken in the literature is to describe possible opportunities and suggestions for librarian-faculty collaboration while describing the many benefits of successful partnerships (Lindstrom and Shonrock, 2006; Mileham et al., 2001).

\section{Project Context}

A Faculty Learning Community (FLC) at Miami University is "a cross-disciplinary faculty and staff group of six to fifteen members who engage in an active, collaborative, yearlong program with a curriculum about advancing teaching and learning" (Cox, 2004). The purpose of the FLC is to provide a structured environment for faculty and staff to meet together and explore some of the teaching and learning issues they encounter in the classroom. These communities are sponsored by Miami University's Center for Learning and Teaching. Cox (2002) provides their detailed history and function at Miami University. 
The FLC focusing on information literacy has been in existence for six years, involving over fifty faculty members during that time [i]. The name of the community has changed several times over the years to clarify its purpose to potential faculty members, who may not be familiar with the term information literacy. The FLC for Improving Student Research Literacy proved to be a more successful name for attracting faculty members. This community consists of twelve total members -- eight faculty and four librarians, including the librarian facilitator. Members meet approximately six times during each semester to discuss information literacy issues, ranging from personal experiences in the classroom to campus-wide integration of information literacy. Each year, the community undertakes a major project to further investigate and improve the research skills of students. Affiliates also collaborate on projects that aim to enhance the research experience in their individual courses. They report back to the group to discuss their progress. For their participation, members receive a professional development stipend, occasional registration for related conferences, and refreshments at the meetings.

The nature of the larger FLC project varies from year to year, depending on the interests and needs of the members. In the 2008/2009 academic year the participants wanted to determine how students perceived their own searching skills, how they looked for information, and where they searched. They created a survey for students enrolled in their classes. The questionnaire was designed to take approximately 10-12 minutes to complete and consisted of Likert-scale questions, multiple-choice responses, and open-ended questions (Appendix A). Since it dealt with human subjects, this survey required approval from the Institutional Review Board (IRB). The responses were kept anonymous, and the instructors were not in the room during survey 
proctoring. They received aggregate results by class. Although survey participation was voluntary and not connected to their course grade, the completion rate was $95 \%$.

Self assessments have primarily been created by librarians to evaluate students' information literacy skills, their learning over the course of a class, or to improve librarians' information literacy instruction (Oakleaf, 2009; Taylor and Atwong, 2008). Librarians at Central Michigan University used student self-assessments as an instructional tool to provide students with feedback regarding their information literacy skills coupled with information about library resources and services (Ivanitskaya et al., 2004). Investigating a possible cause of library anxiety, Haglund and Herron (2008) asked students to self-assess their information literacy skills and compared this information with how well students performed on information literacy tests.

Literature regarding learning communities and information literacy has two major emphases. One emphasis involving student learning communities focuses on incorporating information literacy into their curriculum (Young amd Duvernay, 2006; Lebbin, 2005; Carpenter, 2004). The other describes working with faculty in learning communities and workshops to integrate information literacy into particular courses (Werrell and Wesley, 1990; Chapman and White, 2001).

\section{Findings}

A total of 300 students from fifteen different classes completed surveys (Figure 1). Departments represented did not include the sciences, however science students fulfilling liberal arts 
requirements may have been included in the sample. Students were not asked to indicate their major. Students were primarily from the upper levels, with $62 \%$ of respondents either being a junior or a senior. Sixty percent of students were female. Ninety-six percent of students were between the age of 18 and 22 .

The results of the survey were enlightening for both the librarians and the faculty. Although the findings were not always surprising, they did help us understand better how students perceive information literacy and how they do research. Among the general trends that emerged from the data analysis, the most apparent was students' preference for online resources, such as Google or article databases including those from EBSCO (Figure 2). Respondents who used library resources (online and print materials purchased by the library for student use) exclusively also preferred online library tools. A related trend was a penchant for using Google or Wikipedia first to learn more about their topic and then following up with library research. They did not indicate that they use print or electronic library encyclopedias. One student noted: "I usually start with Google-just as a jumping off point. I avoid Wikipedia altogether. Depending on what my assignment is - I'll go to online newspapers and magazines mostly.”

Prior to seeing the survey results, faculty and librarian members of the learning community were confident in their understanding of students' search behavior. We assumed that students are overly reliant on Internet resources such as Wikipedia and Google. However, only $21 \%$ of students indicated that they exclusively use Google, Wikipedia or both for scholarly research. One of the more revealing responses in this subset was "I get either on Google or Wikipedia. Take the info I want, rephrase it and use it." In contrast to this research technique, $31 \%$ of 
students surveyed said that they solely use library resources, either online or in print. In many responses the feeling of pride of this fact was apparent through words such as "obviously," or the specific mention that Google or Wikipedia were avoided in their scholarly search: "I search online journals, go to the library to search through books and not use Google." The remaining $41 \%$ prefer a combination of library resources and non-library websites and search engines.

Another surprising trend was that most students did not see research as a process and instead listed resources they used when asked to describe their search strategy. We had hoped that students would recognize that there are multiple steps to research. Rather than describing these different steps, they could only think of tools that are used to do research. It was an unexpected trend for our faculty, who assumed that students were already familiar with the concept of research as a process.

Confirming assumptions of faculty, overwhelmingly students expressed their comfort with using technology. Although the students felt confident using technology, it is important to note that their responses do not necessarily reflect their competence, although the faculty often equated the two. An assumption common to the librarians was that students' confidence in using technology is closely linked to their confidence in using online library resources. The graph in Figure 3 illustrates the relationship between these two skills and shows that students view online research skills as very different from general technology proficiency. Responses to other questions confirm their uneasiness with library research. Although $31 \%$ of stuents indicated that they go exclusively to library resources for their research projects, only $23 \%$ of all the respondents strongly agree that they are confident in using them. 
Sadly, there is a possibility that students are unaware of what is available to them and therefore unable to develop their library research skills. One of the respondents sums up this hypothesis in an unexpected way: "I used Ebscohost [sic] some in high school and other similar programs but I don't think I have access to them anymore." It was an unexpected statement to us because in addition to subscribing to numerous databases from EbscoHost, these databases are the most widely promoted. Another student, possibly unaware of the interlibrary loan options, describes a bad research experience as "when I cannot find relevant material, or worse when I can find it, but do not have access to it."

Finally, both instructors and librarians were interested in whether the students make the connection between course-related research assignments and research they do outside of class, either in a job setting or for personal knowledge. The findings suggested that many students saw the value of research assignments and were able to transfer the knowledge gained to other endeavors. In particular, they realized how the research skills they learn in one class can be transferred to another (Figure 4). Fifty-five percent agreed and another $40 \%$ strongly agreed that the skills they used to find scholarly information in one class can be utilized in other classes. The numbers of students who agreed that the skills used in finding scholarly information could be utilized in a job setting was slightly smaller (49\% agree and $24 \%$ strongly disagree), but the numbers were still strong (Figure 5). While student response did not clearly indicate which specific research skills they thought would be useful, it was heartening to find that students recognized how information literacy can contribute to lifelong learning. 
All of the above-mentioned trends helped us determine the areas in which students needed additional help. Librarian members of the community used this information to adjust their library instruction sessions, as well as advising the faculty on additional resources they might use. The faculty members utilized individual results for their classes in order to redesign their courses and make the research process a more prominent part of coursework.

\section{Practical Implications}

After the results of the survey were shared with members of the community, they were challenged to change class syllabi and assignments to address the concerns raised by their class survey results. All faculty members made changes to their syllabi, but three instructors significantly redesigned their courses. These three cases illustrate how this project influenced faculty in different ways. Since each course had unique results, each professor used different approaches for integrating information literacy into their course.

Discussions between the professor of a Philosophy course called Moral Issues in Health Care and the liaison librarian in the learning community led to revisions of the semester long assignment to include information literacy components. Previously, the assignment had several steps and required students to examine a medical case that raised ethical questions using philosophical approaches learned during the semester. Students chose a case from a list in their textbook and completed a free writing exercise discussing their views on the particular case. Then they researched philosophical views on the subject and how others have interpreted those views in similar cases. Finally, after several drafts, they submitted a final version of the paper. The instructor's primary reason for choosing to modify this assignment was his concern that students 
had become passive consumers of information. Cases had to come from the textbook and often did not draw students' interest. They demonstrated little critical thinking skills in researching their topics and were not citing scholarly resources. Instruction on the research process was not provided beyond suggesting databases.

In order to address these concerns several changes and additions were made to the assignment. The redesigned assignment asks students to select a case either from their own experience or from current events, giving them freedom to choose a case related to their own interests. In an additional step, students are asked to formulate and submit research questions related to the medical cases they have chosen. A library instruction session after this step demonstrates research resources and strategies. After the instruction session but prior to submitting a draft version of the paper, students are required to submit a description of their search strategy process as well as a bibliography annotated with a summary of each source and an explanation of how it will be used in their analysis of the case study.

While positive changes were made, they have had limited success. The course is held on a branch campus some distance from the main campus, and only five students (of a possible 25) enrolled in the course. Because of low enrollment, the professor decided to alter the assignment, removing the required library instruction session and instead, embedding librarian contact information and a LibGuide [ii] created specifically for the assignment into course management software. Usage statistics indicate students have used the course guide, but students did not take advantage of the librarian presence in the course software. 
Another member of the FLC was a Theatre professor who taught a graduate research methods class called Introduction to Theatre Research and Methodology. This course is a required class that Theatre graduate students take during the first semester of the program. It focuses on both research methodologies (such as feminist theory or historiography) and methods particular to that discipline, and usually there are about 5-10 students in this class. The professor chose this class for the FLC project because many of the students in this Theatre program come in as practitioners rather than researchers. They may be very good actors or set designers, but they may not have written a research paper for many years. The professor wanted his students to become a part of the academic conversation and to understand the research of the discipline. He was surprised by the survey results that indicated how many students don't understand that research is a process. Revisions that he made, with the help of the Theatre liaison librarian, focused on not just teaching research tools but teaching how and why research is done.

Changes included requiring the students to read The Craft of Research by Wayne C. Booth and expanding the scope of the required annotated bibliography. Students now had to write more in their annotations about why they chose particular resources. A library resources page was included on their course management site, with a link to the relevant LibGuide [iii]. The Theatre liaison librarian taught three individual sessions during the course. Two of those sessions included showing print and electronic resources and talking about different research strategies. The third session was a more informal session where the librarian, the professor, and the students talked about their experiences with research. The students also had a chance during that session to talk about their individual research projects. Finally each student was required to meet oneon-one with the librarian at least once. 
Everyone involved felt that these changes really made the course more valuable. The discussions about research that took place throughout the course were richer because of the readings and the librarian involvement. The professor felt that the annotated bibliographies were stronger than in previous semesters. Several students met with the librarian more than the one required time, and the librarian received very positive evaluations.

Another example of a successful partnership was a professor who taught an undergraduate history course called the United States in the 1960s. It draws heavily on primary documents and historical witnesses. The students' final project was an oral history assignment, which involved completing a documentary on a certain topic. Research for this project was not a formal or graded part of the assignment. Therefore the individual survey results for this class were illuminating for the professor in regards to the students' information literacy skills. Eighty-eight percent of students either agreed or strongly agreed with the statement "I am prepared to do library research," showing their confidence with library resources. Yet, over half of the class indicated that they believe most information they find, while another $34 \%$ were neutral (Figure 6). Still more intriguing were the answers to the question about planning a research strategy before beginning to look for information. Fifty-six percent of students said they do not plan and $13 \%$ were neutral (Figure 7). The professor noted the inconsistency in these responses between the students' confidence and their competence concerning their information literacy skills. She concluded that library research should become a more integral part of the course. 
As a result, the course changed in two fundamental ways. A librarian was embedded into the course [iv] and the final project requirement was enhanced by a graded research component. The professor invited the history liaison librarian to the first class meeting to give the students an opportunity to get acquainted with her and the library resources. In addition, she had a virtual presence in class, having established a library page in the course management software that was used for this class. Another component of librarian presence was the requirement of all students to meet with the history librarian at least twice in the course of the semester.

The other way in which the course has changed involves additional components to the final project. The students are now required to build their own syllabus and provide an annotated bibliography explaining the nature of their resources, as well as why they chose them. This assignment encourages students to conduct their own research on the variety of topics to make their "course" well balanced and informative. Another goal the professor attempted to reach with this assignment is to give the students confidence in distinguishing between valid and invalid secondary sources. With this assignment she emphasized the importance of information evaluating skills, rather than dictating which sources they should use. Although the results of these changes are still uncertain, as is the success of the redesigned syllabus, they are definitely a step in the right direction. Both the faculty member and the students see the library as a more approachable and important resource. From the enthusiasm of the professor working with the history librarian, it was also clear that she never considered us as information literacy allies before. 
The above experiences recount the best of the contributions from the past year's learning community. Other contributions varied in productivity or thoughtfulness. For some, incentives were more important than community learning. For others, a learning community meant discussion and little more. While all group members were receptive to information literacy, putting that knowledge into practice was a challenge for some. During a particularly productive discussion, one member of the community said that there wasn't enough time for information literacy in the classroom. While this assertion was instantly disputed by other members of the community, she was one whose final project did not reflect a great deal of growth. Finally, implementation of some of the projects is still on hold due to extenuating circumstances, such as research leaves and fellowships.

Finally, the survey tool itself provided considerably helpful and useful data, especially considering that it was designed by a large group of individuals. What helped in this regard was that some members of the FLC were quite experienced at designing survey tools. Careful consideration was given to ensure that the survey reflected the interests of the members of the FLC. Little confusion resulted from the wording of the questions, which is very positive considering that the FLC spent hours discussing how to properly word survey questions. However, some of the data collected from the survey (most notably study locations, student trace, and student internet connection) proved to be unhelpful when analyzing results Furthermore, implementing a paper survey caused issues in getting the data to faculty promptly. Considerable time is required for someone to code four hundred surveys. As we consider future prospects for the survey, streamlining the survey content and implementation process are definitely priorities. 


\section{Value and future implications of the Survey Project}

Our survey pool was predetermined because of the faculty involved in the FLC. As a result $60 \%$ of those surveyed were either juniors or seniors with more extensive research experience. $45 \%$ had written at least 15 papers since they started at Miami. Many other projects that have been cited in the literature focus more on the first year experience.

While there are similar studies (Oakleaf, 2009; Taylor and Atwong, 2008; Ivanitskaya et al., 2004) surveying research practices and information literacy skills of students, the Miami University study is distinctive in that it reports on collaboration with faculty and makes use of their perceptions of students in their courses. Miami University is fortunate to have a Faculty Learning Community that focuses on exploring information literacy collaboratively. The structure of the community allowed for good discussions among faculty and librarians, which led to better understanding of each others' perspectives. Too often faculty and librarians do not have enough opportunities to discuss issues that they have in common. The FLC is open to all faculty and librarians across the campus. As a result our community was made up of people from many different disciplines. This study doesn't just report on a specific class or even a specific discipline, but instead reports on the experiences of students across several different disciplines. This project has stretched beyond the one-year time limit of the FLC and has given a start to individual long-lasting collaborations. Many of the faculty and librarians are still working together on improving the information literacy skills of students.

The survey that was created by the FLC members is distinctive in that it was dictated by faculty 
expectations in addition to what librarians wanted to know about students. Self-assessment surveys have primarily been created by librarians to assess students' information literacy skills (Oakleaf, 2009; Taylor and Atwong, 2008). A surprising number of the questions generated by the faculty expressed similar concerns that librarians often have. It was useful to know that we are working towards the same goals. Both faculty and librarians are concerned that students understand how to properly find and evaluate information and that they can transfer these skills to all aspects of their lives.

The chance to collaborate was a fruitful experience for both librarians and faculty. It was a good opportunity for librarians to learn what information literacy skills faculty members expect their students to have. Similarly, this partnership helped faculty to better understand how their students perceive information literacy and the challenges librarians encounter when teaching these skills. Our faculty became more receptive to changing researching assignments and involving librarians in the process as a result of this effort. Librarians at other institutions should consider taking advantage of opportunities to work with faculty to create similar kinds of research projects. Although it is not always possible to work with faculty in a formal venue, there are often other ways to reach out to instructors. Librarians may consider starting with their liaison areas to gauge interest in collaborative projects. Potential advocates for collaborative projects are the centers for learning and teaching that are common at many universities.

Librarians may be surprised by how receptive faculty can be. Although they do not always call it information literacy, instructors are just as concerned as librarians about the research skills of their students.

\section{Notes}


i. $\quad$ http://www.units.muohio.edu/celt/faculty/flcs/miami/0910/literacy.php

ii. $\quad$ http://libguides.lib.muohio.edu/content.php?pid=42959\&sid=634247

iii. http://libguides.lib.muohio.edu/theatre

iv. $\quad$ http://libguides.lib.muohio.edu/content.php?pid=43611\&sid=471976

\section{References}

Carpenter, C. (2004), "A learning community connects with the Information Literacy Standards", College \& Research Libraries News, Vol. 65 No. 8, pp. 425.

Chapman, J., and White, M. (2001), "Building bridges with faculty: The evolution and outcomes of library workshops for faculty at Valdosta State University" Technical Services Quarterly, Vol. 19 No. 1 , pp. 25-36.

Cox, M. (2004), "Introduction to faculty learning communities", New Directions for Teaching and Learning, Vol. 97, pp. 5-23.

Cox, M. (2002), "The role of community in learning: Making connections for your classroom and campus, your students and colleagues", In G. S. Wheeler (Ed.), Teaching and Learning in College: A Resource for Educators, Info-Tec, Elyria, $\mathrm{OH}$.

Deitering, A., and Jameson, S. (2008), "Step by step through the scholarly conversation: A collaborative library/writing faculty project to embed information literacy and promote critical thinking in first year composition at Oregon State University", College \& Undergraduate Libraries, Vol. 15 No. 1/2, pp. 57-79. 
Haglund, L., and Herron, D. (2008), "Students with non-proficient information seeking skills greatly over-estimate their abilities", Evidence Based Library and Information Practice, Vol. 3 No. 2, pp. 48-51.

Ivanitskaya, L., Laus, R., and Casey, A. (2004), "Research readiness self-assessment: Assessing students' research skills and attitudes", Journal of Library Administration, Vol. 41 No. 1/2, pp. 167-183.

Lampert, L. (2005), "'Getting psyched' about information literacy: A successful faculty-librarian collaboration for educational psychology and counseling", Reference Librarian, Vol. 43 No. 89/90, pp. 5-23.

Lebbin, V. (2005), "Students perceptions on the long-range value of information literacy instruction through a learning community", Research Strategies, Vol. 20 No. 3, pp. 204-218.

Lindstrom, J., \& Shonrock, D. (2006), "Faculty-librarian collaboration to Achieve Integration of Information Literacy", Reference \& User Services Quarterly, Vol. 46 No. 1, pp. 18-23.

Love, M., \& Norwood, S. (2007), "Finding our way as 'embedded librarians", College \& Undergraduate Libraries, Vol. 14 No. 4, pp. 87-93.

Mileham, P., Ruelle, J., \& Berry, S. (2001), "Playing well with others: Increasing your librarycampus partnerships", Collection Management, Vol. 26 No. 3, pp. 77-87. 
Oakleaf, M. (2009), "The information literacy instruction assessment cycle", Journal of Documentation, Vol. 65 No. 4, pp. 539-560.

Taylor, L., and Atwong, C. (2008), "Integrating information literacy into business education: A successful case of faculty-librarian collaboration", Journal of Business \& Finance Librarianship, Vol. 13 No. 4, pp. 433-449.

Werrell, E., and Wesley, T. (1990), "Promoting information literacy through a faculty workshop", Research Strategies, Vol. 8 No. 4, pp. 172-180.

Young, S., and Duvernay, J. (2006), "Learning communities and librarians at Arizona State University", IATUL Annual Conference Proceedings, Vol. 16, pp. 62-66.

\section{Further reading}

Badke, W. (2005), "Can't get no respect: Helping faculty to understand the educational power of information literacy", Reference Librarian, Vol. 43 No. 89/90, pp. 63-80.

Bennett, O., and Gilbert, K. (2009), "Extending liaison collaboration: partnering with faculty in support of a student learning community", Reference Services Review, Vol. 37 No. 2, pp. 131142. 
Ellison, A. (2004), "Positive faculty/librarian relationships for productive library assignments",

Community \& Junior College Libraries, Vol. 12 No. 2, pp. 23-28.

Gross, M., and Latham, D. (2009). "Undergraduate perceptions of information literacy: Defining, attaining, and self-assessing skills", College \& Research Libraries, Vol. 70 No. 4, pp. 336-350.

This survey is meant to determine your perceptions on searching and finding information. The information gained from this survey will be used by faculty members to enhance assignments to better reflect what students already know about finding information. We also will share this information with librarians and faculty members outside the university via publication.

You may choose to answer any/all of the questions in the survey, and do not have to complete the survey as a requirement for this class (and you will not be penalized for not taking the survey). Your instructor will not know who completed the survey. Completion of the survey indicates that you give your consent to participate in this project, and use the data as described above.

Please choose one: I am Age 18 or Older Under Age 18

On how many papers or projects have you had to use outside sources while at Miami?

\begin{tabular}{|l|l|l|l|l|l|l|}
\hline $0-3$ & $4-7$ & $8-11$ & $12-15$ & More than 15 & $\begin{array}{l}\text { Don't } \\
\text { Know }\end{array}$ & $\begin{array}{l}\text { Not } \\
\text { Applicable }\end{array}$ \\
\hline
\end{tabular}

In one paragraph, describe your process as you search for information. Where do you go? How do you search? What is your usual search strategy?

What online resources do you utilize most often for paper/project research?

In your opinion, what is the difference between a good research experience and a bad research experience?

When you reach a dead-end when searching (meaning that you are diligently searching, but still cannot find any relevant information), what do you do?

Please think about the work you do for your research assignments and indicate whether you agree or disagree with the following statements:

\begin{tabular}{|l|l|l|l|l|l|l|l|}
\hline & $\begin{array}{l}\text { Strongly } \\
\text { Disagree }\end{array}$ & Disagree & Neutral & Agree & $\begin{array}{l}\text { Strongly } \\
\text { Agree }\end{array}$ & DK & NA \\
\hline
\end{tabular}




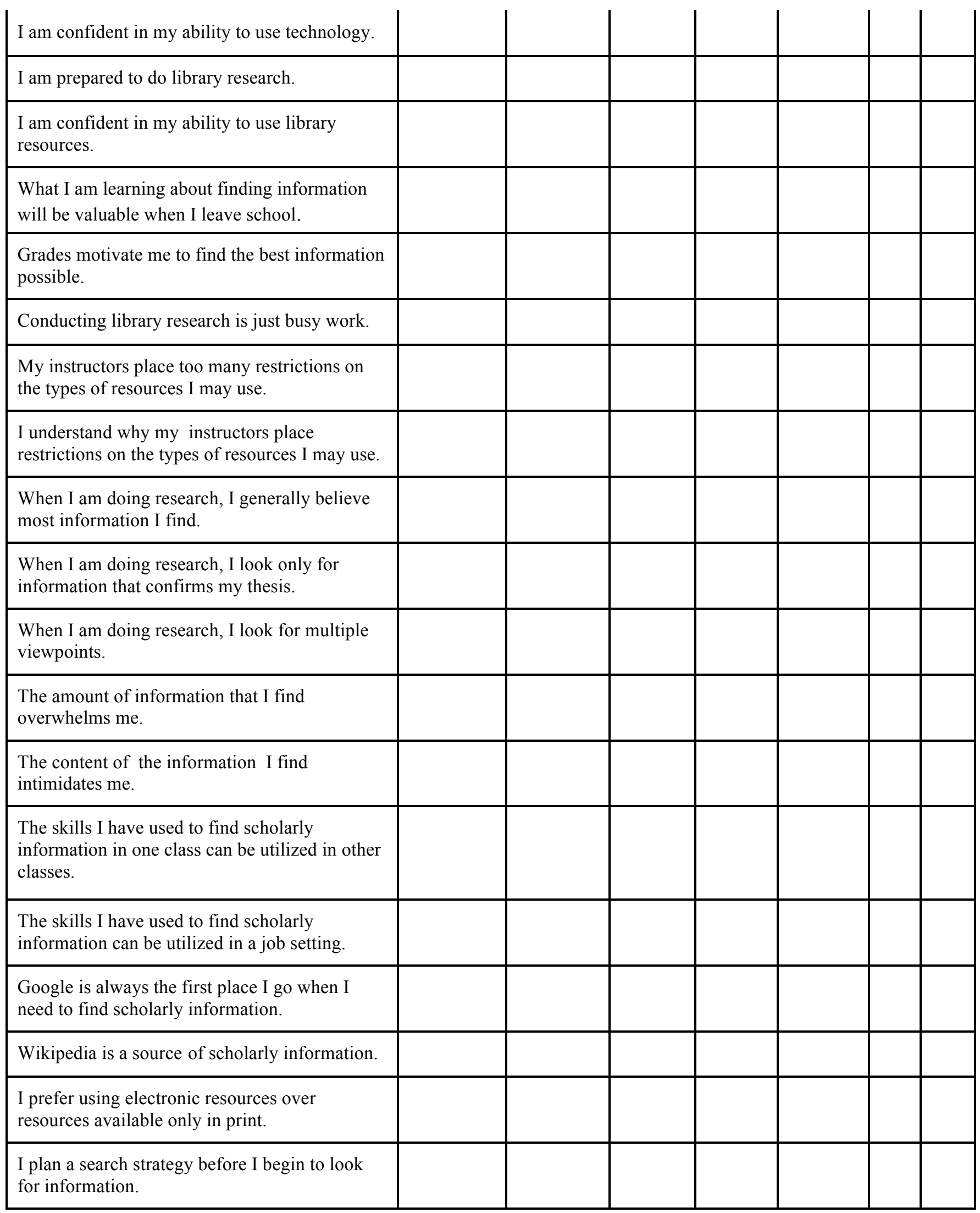


Searching for information is a trial and error process (I enter words until I find what I want).

I can locate resources in the library.

When you study for your courses, how often do you study at the following locations?

\begin{tabular}{|l|l|l|l|l|l|l|l|}
\hline & Rarely & $\begin{array}{l}\text { Sometime } \\
\mathrm{s}\end{array}$ & $\begin{array}{l}\text { Regular } \\
\text { ly }\end{array}$ & $\begin{array}{l}\text { Freque } \\
\text { ntly }\end{array}$ & $\begin{array}{l}\text { All the } \\
\text { time }\end{array}$ & DK & NA \\
\hline King Library (or other Oxford campus library) & & & & & & & \\
\hline Miami Hamilton Library & & & & & & & \\
\hline Miami Middletown Library & & & & & & & \\
\hline Dorm/Apartment/House & & & & & & & \\
\hline Shriver Center & & & & & & & \\
\hline Classroom Building & & & & & & & \\
\hline Lane (or other) Public Library & & & & & & & \\
\hline Other & & & & & & & \\
\hline
\end{tabular}

When you need information for a paper, how often do you use the following resources?

\begin{tabular}{|l|l|l|l|l|l|l|l|}
\hline & Rarely & $\begin{array}{l}\text { Sometime } \\
\text { s }\end{array}$ & $\begin{array}{l}\text { Regular } \\
\text { ly }\end{array}$ & $\begin{array}{l}\text { Freque } \\
\text { ntly }\end{array}$ & $\begin{array}{l}\text { All the } \\
\text { time }\end{array}$ & DK & NA \\
\hline Google (or another search engine) & & & & & & & \\
\hline Course textbook & & & & & & & \\
\hline The library catalog & & & & & & & \\
\hline Database of scholarly journals & & & & & & & \\
\hline Google Scholar & & & & & & & \\
\hline Wikipedia & & & & & & & \\
\hline Friends or colleagues & & & & & & & \\
\hline Professor/TA & & & & & & & \\
\hline Librarian (in person consulation) & & & & & & & \\
\hline
\end{tabular}




\begin{tabular}{|l|l|l|l|l|l|l|l|} 
Librarian (via IM or chat) & & & & & & & \\
\hline Librarian (via text message) & & & & & & & \\
\hline Other (please specify) & & & & & & & \\
\hline
\end{tabular}

\section{Class Standing}

\begin{tabular}{|c|c|c|c|c|l|}
\hline $\begin{array}{c}\text { Freshman (less than } 30 \\
\text { credit hours })\end{array}$ & $\begin{array}{c}\text { Sophomore } \\
(30-63 \text { credit }\end{array}$ & $\begin{array}{c}\text { Junior } \\
(64-95 \text { credit }\end{array}$ & $\begin{array}{c}\text { Senior } \\
(96+\text { credit hours })\end{array}$ & $\begin{array}{c}\text { Graduate } \\
\text { Student }\end{array}$ & Other \\
\hline
\end{tabular}

Age

\begin{tabular}{|ll|l|l|l|}
\hline Under 18 & $18-22$ & $23-29$ & $30-39$ & $40+$ \\
\hline
\end{tabular}

Race/Ethnicity (check all that apply)

\begin{tabular}{|l|l|l|l|l|l|l|}
\hline $\begin{array}{l}\text { African-American/ } \\
\text { African/ Black }\end{array}$ & $\begin{array}{l}\text { Native American/ } \\
\text { Alaskan Native }\end{array}$ & $\begin{array}{l}\text { Asian } \\
\text { Ameri }\end{array}$ & $\begin{array}{l}\text { Asian, incl. Indian } \\
\text { subcon. }\end{array}$ & $\begin{array}{l}\text { Hispanic/ } \\
\text { Latino }\end{array}$ & $\begin{array}{l}\text { Mexican } \\
\text { American }\end{array}$ & $\begin{array}{l}\text { Puerto } \\
\text { Rican }\end{array}$ \\
\hline $\begin{array}{l}\text { Native Hawaiian, } \\
\text { Pacific Islander }\end{array}$ & $\begin{array}{l}\text { White or } \\
\text { Caucasian }\end{array}$ & Other & $\begin{array}{l}\text { Do not wish to } \\
\text { answer }\end{array}$ & & & \\
\hline
\end{tabular}

Gender

\begin{tabular}{|l|l|}
\hline Male & Female \\
\hline
\end{tabular}

Estimated Current GPA

\begin{tabular}{|l|l|l|l|l|l|l|}
\hline $4.0-3.5$ & $3.49-3.0$ & $2.99-2.5$ & $2.0-2.49$ & $1.99-1.5$ & $1.49-1.0$ & $\begin{array}{l}\text { Less } \\
\text { than } 1.0\end{array}$ \\
\hline
\end{tabular}

